\title{
Subretinal pigment epithelial infiltrates in primary vitreoretinal lymphoma
}

\author{
Daniel Vítor Vasconcelos-Santos • Gustavo Henrique De Puy e Souza • \\ Bernardo Bacelar de Faria • Moisés Salgado Pedrosa • André Vasconcellos Diniz • \\ Juliana Lambert Oréfice $\cdot$ Rogério Alves Costa $\cdot$ Fernando Oréfice
}

Received: 10 June 2011 / Accepted: 18 July 2011 / Published online: 6 August 2011

(C) The Author(s) 2011. This article is published with open access at SpringerLink.com

\begin{abstract}
A 67-year-old woman with chronic bilateral intraocular inflammation associated with vitreous cells and subretinal pigment epithelium (RPE) infiltrates (A-B) underwent a chorioretinal biopsy in the left eye after three negative vitreous biopsies. Sub-RPE deposits on spectral domain optical coherence tomography $(\mathrm{C})$ corresponded to collections of diffuse large B-cell lymphoma cells on histopathogy (D-E) and immunohistochemistry $(\mathrm{F}-\mathrm{H})$.
\end{abstract}

D. V. Vasconcelos-Santos · G. H. De Puy e Souza •

B. B. de Faria $\cdot$ M. S. Pedrosa

Department of Pathology, Universidade Federal de Minas Gerais,

Belo Horizonte, Brazil

D. V. Vasconcelos-Santos · A. V. Diniz · J. L. Oréfice •

R. A. Costa $\cdot$ F. Oréfice

Centro Brasileiro de Ciências Visuais,

Belo Horizonte, Brazil

D. V. Vasconcelos-Santos $(\bowtie)$

Rua dos Ottoni 881/1001,

Belo Horizonte, MG 30150-270, Brazil

e-mail: dvitorvs@gmail.com
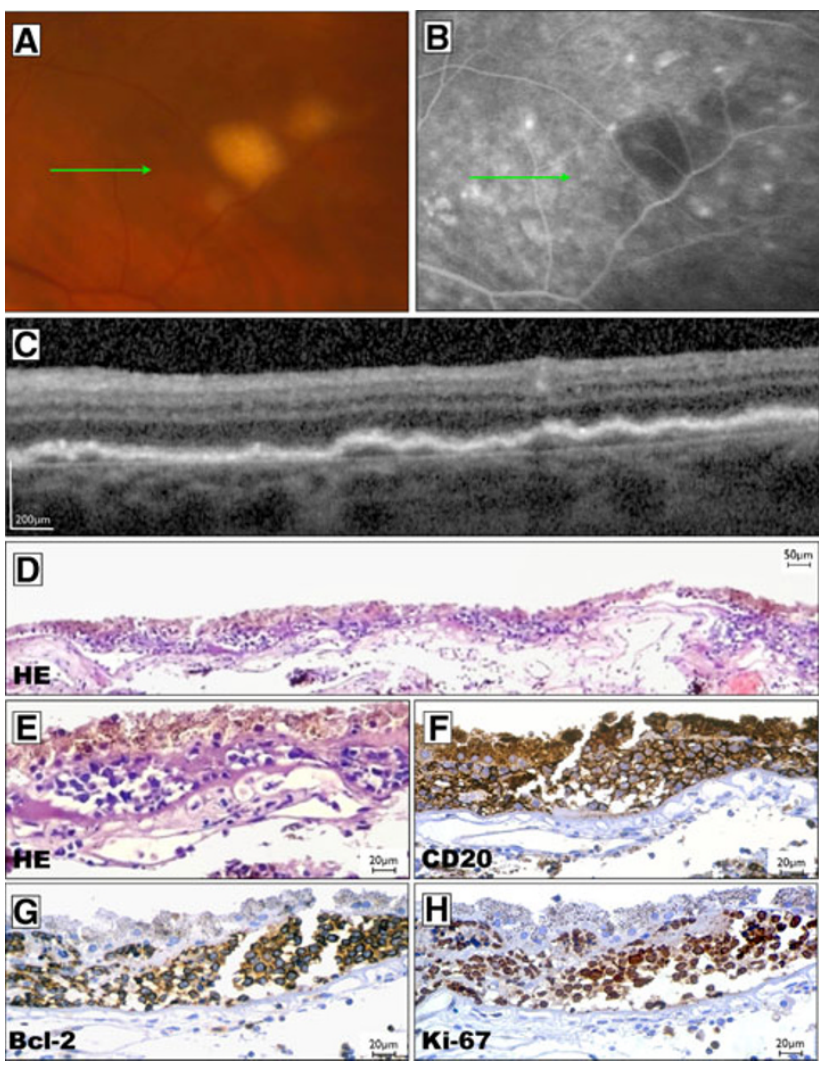

Acknowledgment The authors acknowledge Victório Vinciguerra Neto, COMT for his work in capturing part of the images.

Conflict of interest The authors have no financial interest to disclose.

Open Access This article is distributed under the terms of the Creative Commons Attribution License which permits any use, distribution and reproduction in any medium, provided the original author(s) and source are credited. 